Sains Malaysiana 50(2)(2021): 383-393

http://dx.doi.org/10.17576/jsm-2021-5002-10

\title{
Antimicrobial Activity and LC-MS Data Comparison from Lichen Parmotrema praesorediosum in Bangi, Selangor, Malaysia
}

(Aktiviti Antimikrob dan Perbandingan Data LC-MS daripada Lichen Parmotrema praesorediosum di Bangi, Selangor, Malaysia)

\author{
Anis Asmi Azman, Nurul Nadiah, Andi Rifki Rosandy, Afnani Alwi, Nurkhalida Kamal, Rozida Mohd \\ KHALID \& MUNTAZ ABU BAKAR*
}

\begin{abstract}
The research study regarding antimicrobial activity of pure compounds and LCMS data comparison from extract of lichen Parmotrema praesorediosum in Bangi, Selangor, Malaysia. Antimicrobial activity of acetone, ethanol, and methanol extracts as well as five compounds, namely methyl divaricatinate, methyl haematommate, methyl chlorohaematommate, methyl $\beta$-orsellinate, and vinapraesorediosic acid from methanol extract were identified for the microbial activity against four bacterial species, Staphylococcus aureus, Methicillin-resistant Staphylococcus aureus, Enterobacter aerogens, and Escerichia coli as well as two fungal species, Candida albicans and Candida parapsilosis based on standards. The determination of $I C_{50}$ using minimal inhibitory concentration (MIC) by broth microdilution method was carried out. For acetone extract, $201 \mu \mathrm{g} / \mathrm{mL}$ concentration was required to inhibit 50\% (IC $\left.{ }_{50}\right)$ growth of positive gram bacteria, S. aureus while the concentrations of 430 and $480 \mu \mathrm{g} / \mathrm{mL}$ were able to inhibit $50 \%\left(\right.$ IC $\left.C_{50}\right)$ growth of C. albicans and C. parapsilosis, respectively. Ethanol and methanol extract as well as five pure compounds did not inhibit $50 \%\left(I C_{50}\right)$ of bacterial and yeast growths. Five pure compounds were first reported to determine IC ${ }_{50}$ of minimal inhibitory concentration (MIC) from lichen, Parmotrema praesorediosum in Malaysia. The comparison of LC-MS data between ethanol and acetone extracts showed that there was a peak of the main compound, atranorin in the acetone extract, but was invisible in the ethanol extract where the main bond broke down and produced other compounds. Result of pure compounds from antimicrobial activity and LCMS data comparison from extract of lichen Parmotrema praesorediosum were first reported in Bangi, Selangor, Malaysia. Data produced from this study will be used to show the comparison and latest result that will provide ongoing body of research into the issue of natural product.
\end{abstract}

Keywords: Antimicrobial; LC-MS; lichen; MIC

\section{ABSTRAK}

Penyelidikan ini mengkaji tentang aktiviti antimikrob bagi sebatian tulen dan perbandingan data SJ-CK daripada ekstrak lichen Parmotrema praesorediosum di Bangi, Selangor, Malaysia. Aktiviti antimikrob bagi ekstrak aseton, etanol dan metanol serta lima sebatian, iaitu metil divarikatinat, metil haematomat, metil klorohaematomat, metil $\beta$-orselinat dan asid vinapraesorediosik daripada ekstrak metanol dikenal pasti untuk aktiviti mikrob terhadap empat spesies bakteria, Staphylococcus aureus, rintang metisilin Staphylococcus aureus, Enterobacter aerogens dan Escerichia coli serta dua spesies yis, Candida albicans dan Candida parapsilosis berdasarkan piawai. Penentuan IC s0 $_{\text {menggunakan }}$ kepekatan perencatan minimum (KPM) dengan kaedah mikrodilusi kaldu dilakukan. Bagi ekstrak aseton, kepekatan $201 \mu \mathrm{g} / \mathrm{mL}$ berupaya untuk merencatkan 50\% (IC $\left.{ }_{50}\right)$ pertumbuhan bakteria gram positif, S. aureus manakala kepekatan sebanyak 430 dan $480 \mu \mathrm{g} / \mathrm{mL}$ berupaya merencatkan 50\% (IC $\left.{ }_{50}\right)$ pertumbuhan yis C. albicans dan C. parapsilosis. Ekstrak etanol dan metanol serta lima sebatian tulen tidak berupaya untuk merencatkan 50\% pertumbuhan bakteria dan yis. Lima sebatian tulen pertama kali dilaporkan untuk menentukan kepekatan perencatan minimum (KPM) IC ${ }_{50}$ daripada liken Parmotrema praesorediosum di Malaysia. Perbandingan data SJ-CK antara ekstrak etanol dan aseton menunjukkan terdapat puncak sebatian utama, atranorin dalam ekstrak aseton, tetapi tidak kelihatan pada ekstrak etanol dengan pecahan ikatan utama telah berlaku dan menghasilkan sebatian lain. Keputusan bagi sebatian tulen daripada aktiviti antimikrob dan perbandingan data SJ-CK daripada ekstrak lichen Parmotrema praesorediosum pertama kali dilaporkan di Bangi, Selangor, Malaysia. Data yang dihasilkan daripada kajian ini akan digunakan untuk menunjukkan perbandingan dan hasil terbaru yang akan memberikan kajian yang berterusan mengenai isu produk semula jadi.

Kata kunci: Antimikrob; KPM; liken; SJ-CK 


\section{INTRODUCTION}

Lichen is a mutualism symbiosis between alga (photobion) and fungus (mycobion) in which both organisms benefit from each other (Goga et al. 2018). Parmotrema is a genus derived from the Parmeliacea family, Lecanorales order and Lecanoromycetes class. With more than 2,000 species in about 87 genus, it is considered the largest family of fungi to form fungus (Huynh 2014; Huynh et al. 2016). A majority of lichen enlargement for Parmeliacea species are foliose, fruticose, and crustose (Thell et al. 2012). There are two types of metabolites present in lichen, which are primary and secondary metabolites.

A majority of organic compounds present in lichen are secondary metabolites and until now more than 800 secondary metabolites have been reported (Ranković $\&$ Kosanić 2015). Lichen has been used for medical purposes since ancient times and was recognized in the production of unique secondary metabolites, such as aliphatic, aromatic, depsides, depsidone, and pulvinic acid derivatives. Secondary metabolites in the lichen were reported to have potential in biological fields and can act as antibiotics, antimicrobials, analgesic, anti-inflammatory, cytotoxic, anticancer, antiviral, and antiproliferative activity (Goga et al. 2018).

From two different research studies, the antibacterial potential of the Parmotrema species, Parmotrema grayanum, Parmotrema tinctorum, and Parmotrema praesorediosum was tested against three Gram positive bacteria, five Gram negative bacteria and two yeast using the agar dilution method. Overall, the lichen extract showed higher inhibitory activity against Gram-positive bacteria than the negative Gram bacteria and yeast. Among the three species of Parmotrema, Parmotrema grayanum showed high inhibitory activity against the bacteria and yeast (Vivek et al. 2014a, 2014b).

Antimicrobial studies using disc dilution method were also performed on Parmotrema praesorediosum using different solvent extracts namely hexane, acetone, methanol, dichloromethane, and ethyl acetate. It had been tested with eleven microorganisms. Overall, the results showed dichloromethane and ethyl acetate extract showed more antibacterial and antifungal activity than methanol and acetone extract while hexane extract showed no inhibitory activity (Balaji \& Hariharan 2007). In addition, further studies were conducted on Parmotrema species using two different extracts namely aqueous and methanol extract on thirteen different microorganisms using the Kirby-Baeur method. The results showed that aqueous extract did not show any antibacterial or antifungal activity whereas methanol extract showed antimicrobial activity (Chauhan \& Abraham 2013). With this background information, the aim of the present study was to evaluate the antimicrobial activity of lichen Parmotrema praesorediosum extracts and some secondary compounds isolated from methanol extracts. This was because most of them from past research studies used the extract lichen Parmotrema praesorediosum for antimicrobial activity from different geographic location. Therefore, in this research, the used of Parmotrema praesorediosum had be chosen because of their abundancy and the pure compounds found in that lichen were first time reported based on location in UKM, Bangi, Selangor, Malaysia.

Besides that, the type of solvents used for extraction is important for producing effective extraction. This is because the main principle in the extraction of natural compound is to make sure that the original compound required does not break. Therefore, proper extraction should be taken into account for non-destructive bioactive compounds (Jahromi 2019). The use of solvents such as ethanol, methanol, acetone, ethyl acetate, and a combination of these solvents are usually used to extract polyphenolic compounds from plant sources. The solvent selection will affect the amount and rate of extraction for the polyphenolic compound (Altemimi et al. 2017). Polyphenolics are widely distributed in plant kingdoms and are the most common secondary chemical compounds found in plants, including lichen. Lichen is a composite organism consisting of fungus and alga in which alga can conduct photosynthesis similar to plants. That is why lichen extraction was the same as plant extraction because mostly the secondary metabolites in lichens were same as in plants (Goga et al. 2018). These polyphenolics are divided into different classes, depending on basic chemical structures, such as phenolic acid, flavonoids, and depsides. All these polyphenolic compounds consist of at least one aromatic ring attached to one or more hydroxyl groups (Minatel et al. 2017). Generally, the methanol solvent is said to be an effective solvent for the extraction of polyphenolic compounds for low molecular mass, while acetone solvent is suitable for the extraction of flavanol compounds for high molecular mass (Dai \& Mumper 2010). Ethanol solvents are suitable for extracting polyphenolic compounds and are safe for human consumption. This is because ethanol solvent is less toxic compared to the more toxic methanol solvent which is harmful to humans (Joshi \& Adhikari 2019).

In addition, previous study showed that phenolic compounds were easy to hydrolyze and oxidize. Long extraction times and high temperatures are some of the factors that will cause oxidization of these phenolic compounds and reduce the final outcome of the extraction. The types of extraction selected are also necessary 
to maintain the stability of phenolic compounds. Conventional extraction methods, such as maceration and soxhlet are less effective and cause environmental pollution due to the use of organic solvent in large quantities, with a long extraction time (Zhang et al. 2018).

Many factors need to be taken into account to get pure chemical compounds, especially polyphenolic components, as this research study used a lichen as a plant source since it is rich in polyphenolic compounds. Therefore, in this study, the difference in solvent polarity should be considered because the polyphenolic compounds, in particular, contain ester bond that is fragile (Niaounakis 2013). Previous studies contain no strong data to support the effects of using different types of solvents. Therefore, in this study, the lichen sample had been sent for analysis using LC-MS and the data had been used to support the solvents' difference which has become the factor which causes the breakdown of compounds.

\section{MATERIALS AND METHODS}

\section{MATERIALS}

Parmotrema praesorediosum was collected around Universiti Kebangsaan Malaysia (UKM) campus in Bangi, Selangor. The lichen sample was cleared from mosses, soil, and leaves using forceps. Then it was dried at room temperature.

\section{GENERAL EXPERIMENTAL PROCEDURE}

For thin layer chromatography (TLC): silica gel $60 \mathrm{~F}_{254}$ precoated aluminium plates $(0.2 \mathrm{~mm}$, Merck). Vacuum Liquid Chromatography (VLC) Silica gel 60 (1.07747 Merck). Radial Chromatography (RC) Silica gel gypsum 60 (1.07749 Merck). Detection: UV fluorescence and spraying of $10 \% \mathrm{H}_{2} \mathrm{SO}_{4}$, followed by heating on a hot plate (Din et al. 2010). Basic ${ }^{1} \mathrm{H}$ - and ${ }^{13} \mathrm{C}$-NMR (Nuclear Magnetic Resonance) spectroscopy were measured with Bruker $400 \mathrm{MHz}$ and $600 \mathrm{MHz}\left({ }^{1} \mathrm{H}\right)$ and $100 \mathrm{MHz}\left({ }^{13} \mathrm{C}\right)$. The sample was diluted in $\mathrm{CDCl}_{3}$. FTIR spectroscopy was measured with Perkin Elmer Spectrum 400 FT IR/ FT-NIR. ESI-MS was recorded by using spectrometer Bruker Micro ToF-Q.

\section{PREPARATION OF LICHEN EXTRACTS}

Finely ground dry thalli were extracted in $2.9 \mathrm{~g}$ of acetone, $2.7 \mathrm{~g}$ of ethanol, and $629 \mathrm{~g}$ of methanol solvents by using maceration method for nine days. For every three consecutive days $(3 \times 72 \mathrm{~h})$, the samples were filtered and dried using rotary evaporator to yield $119 \mathrm{~g}$ of methanol, $0.20 \mathrm{~g}$ of acetone and $0.35 \mathrm{~g}$ of ethanol extracts. The methanol extract was then subjected to Vacuum Liquid Chromatography (VLC) eluted with hexane-ethyl acetate in order of increasing polarity to give 10 fractions (F1F10). The purification of fractions $1(3.1 \mathrm{~g}), 2(2.6 \mathrm{~g})$ and 3 (0.5 g) using Radial Chromatography (RC) eluted with hexane-ethyl acetate yielded compounds 1 (11 mg), 2 (69 $\mathrm{mg})$ and $3(100 \mathrm{mg})$ from fractions 1,2 and 3 as well as compounds $4(58 \mathrm{mg})$ and $5(5 \mathrm{mg})$.

\section{BACTERIA STRAINS AND MEDIA}

Lichen extracts and five pure compounds were tested against: Gram positive bacteria: Staphylococcus aureus (ATCC 11632), Methicillin-resistant Staphylococcus aureus (ATCC 43300), Gram negative bacteria: Escherichia coli (ATCC 10536), Enterobacter aerogens (ATCC 13048) and fungal, namely Candida albicans (ATCC 14053) and Candida parapsilosis (ATCC 22019). All of them were obtained from the Microbiology laboratory at the Faculty of Science and Technology, UKM, Bangi, Selangor. All glycerol stock for yeast and bacterial were stored at $-80{ }^{\circ} \mathrm{C}$. Bacterial and yeast cultures were maintained in Nutrient Agar (NA) and Potato Dextrose Agar (PDA), respectively and stored at $4{ }^{\circ} \mathrm{C}$.

\section{MICROBE PREPARATION}

One isolated colony for each strain of bacteria and yeast was inoculated within $20 \mathrm{~mL}$ of Nutrient Broth (NB) and Potato Dextrose Broth (PDB) using their respective sterile toothpicks. The $20 \mathrm{~mL}$ tube was then incubated at 37 ${ }^{\circ} \mathrm{C}$ for $16 \mathrm{~h}$ or until the bacteria density reached $1.5 \times$ $10^{8} \mathrm{cfu} / \mathrm{mL}$ (equivalent to $0.5 \mathrm{McF}$ arland turbidity) for bacteria and $1.5 \times 10^{7} \mathrm{cfu} / \mathrm{mL}$ for yeast. The bacterial and yeast densities were measured by spectrophotometers at a wavelength of $625 \mathrm{~nm}$ (OD625).

\section{ANTIMICROBIAL ASSAY}

The Minimal Inhibitory Concentration (MIC) of the lichen samples is determined using a 96-well-plate-based method as described by Eloff (2019) with slight modification. The weight of methanol, ethanol, and acetone extracts as well as five pure compounds obtained from the methanol extract used was $2 \mathrm{mg} / \mathrm{mL}$. Each sample was diluted with chloroform and methanol solvents and added with sterilized distilled water. The final concentration of each extract and pure compounds was $500 \mu \mathrm{g} / \mathrm{mL}$. The working solution was serially diluted in two folds using $100 \mu \mathrm{L}$ sample and the concentration range was 500, 250, 125, 62.5 , and $31.25 \mu \mathrm{g} / \mathrm{mL}$. Each well contained $50 \mu \mathrm{L}$ Nutrient Broth for bacteria and $50 \mu \mathrm{L}$ Potato Dextrose Broth for yeast as diluent. Each well was also inoculated with 50 $\mu \mathrm{L}$ of bacterial and yeast suspension. The positive control 
used was chloramphenicol for bacteria and nystatin for yeast (Mahdavi et al. 2017) with a concentration of 500 $\mu \mathrm{g} / \mathrm{mL}$. The $96-w e l l-p l a t e$ was then incubated at $37^{\circ} \mathrm{C}$ for $16 \mathrm{~h}$ and the reading was taken the next day using ultra-violet spectrometer at $600 \mathrm{~nm}$ wavelength. The readings were compiled and calculated using the formula to obtain the reading percentage of the inhibition. All values were reported as mean \pm standard deviation (SD) of six replicates.

Inhibition of bacteria and yeast growth (\%)

$=\frac{A c-A t}{A C} \times 100$

$A_{c}$ is the average of six replicates of light absorption values at wavelength $610 \mathrm{~nm}$ of growth control; and $\mathrm{A}_{t}$ is the average of six replicates of light absorption values at wavelength $610 \mathrm{~nm}$ of samples.

\section{LC-MS ANALYSIS}

One mg of extract was dissolved in $1 \mathrm{~mL}$ of $\mathrm{MeOH}$ and filtered with C18 cartridges, Sep-Pak (Waters, Milford, USA). The mass spectrum was recorded using an Exactive Spectrometer with an electro-ionization source connected to Accela 600 HPLC pump and Accela automatic sampler. It was detected at $280 \mathrm{~nm}$ and $360 \mathrm{~nm}$ with a UV/Vis detector (Thermo Scientific, Bremen, Germany) with an Orbitrap Exactive mass spectrometer (Thermo Fisher Scientific, Inc). Analysis was carried out at $150-1500 \mathrm{~m} / \mathrm{z}$ range in positive and negative ionizing mode, $4.5 \mathrm{kV}$ spray voltage and capillary temperature at $320^{\circ} \mathrm{C}$. Analytical separation was carried out using column ACE C18 $(5 \mu \mathrm{m}$ $\times 75 \mathrm{~mm} \times 3 \mathrm{~mm}$ ) (Hichrom Limited, Reading, UK) along with water moving phase as well as $0.1 \%$ of formic acid (Solvent A) and $\mathrm{MeCN}$ with $0.1 \%$ formic acid (Solvent $\mathrm{B})$. The gradient program started with $10 \% \mathrm{~B}$ and $\mathrm{B}$ was increased linearly in $30 \mathrm{~min}$ to $100 \%$ at a flow rate of $300 \mu \mathrm{L} / \mathrm{min}$ and remained isocratic for $5 \mathrm{~min}$ before linearly decreasing in $1 \mathrm{~min}$ to $10 \% \mathrm{~B}$. The total analysis time for each sample was $45 \mathrm{~min}$. The injection volume was $10 \mu \mathrm{L}$ and the tray temperature was maintained at $12{ }^{\circ} \mathrm{C}$. Initially, the raw HR-LCMS data were sliced into two data sets based on the ionization mode using the MassConvert tool from ProteoWizard. The sliced data sets were imported into MZmine 2.10 (a software developed for differential analysis of mass spectrometry data). Next, the data was exported as a CSV file. The data from MZmine 2.10 was coordinated with Excel macro database for peak identification and de-replication. The data in the CSV file was exported to SIMCA-P V 14.0 software (Umetrics, Umeå Sweden). For de-replication analysis, the databases were referenced as Dictionary Natural Product (DNP) 2012 and AntiMarin.

\section{RESULTS AND DISCUSSION}

The results (Table 1) show the antimicrobial activity of acetone, ethanol, and methanol extracts as well as their secondary metabolites, which were methyl divaricatinate 1 , methyl haematommate 2 , methyl chlorohaematommate 3 , methyl $\beta$-orsellinate 4 , and vinapraesorediosic acid 5 (Huynh 2014) against two Gram-positive bacteria, two Gram-negative bacteria and two yeasts. Antimicrobials are agents used to kill or inhibit the growth of microorganisms (Mahira et al. 2019) but bacteria or pathogens are constantly evolving, thus causing antibiotics resistance that inhibits their growth (Jim 2014). There are many methods that can be used to study antimicrobial activity in the lichen, such as disk diffusion, agar diffusion, and broth dilution methods (Kosanić \& Ranković 2015). In this research, the broth dilution method was used because it is a quantitative analysis and more accurate than the two other methods that use qualitative analysis (Rajan et al. 2015). This method was used to obtain the minimum inhibition concentration (MIC). MIC is the minimal concentration of antibiotics in inhibiting the growth of microorganisms after incubation at $37^{\circ} \mathrm{C}$ for $24 \mathrm{~h}$ (Kosanić \& Ranković 2015). In this study, the minimum concentration value will be calculated based on the inhibition $50\left(\mathrm{IC}_{50}\right)$ concentration. The sample concentration, $\mathrm{IC}_{50}$ or antibiotic is needed to inhibit 50\% growth of microorganisms.

Table 1 shows the inhibition $50\left(\mathrm{IC}_{50}\right)$ concentration, which means the concentration of samples or antibiotics needed to inhibit $50 \%$ growth of microorganisms. It shows that a total of $201 \mu \mathrm{g} / \mathrm{mL}$ of acetone extract and 110 $\mu \mathrm{g} / \mathrm{mL}$ of chloramphenicol were capable of inhibiting $50 \%$ growth of $S$. aureus. Then, there was no value for sample concentration and antibiotics as the percentage of inhibition did not reach $50 \%$ to inhibit the growth of microorganisms for MRSA and E. coli bacteria of acetone extracts. Similarly, for $E$. aerogenes bacteria, there was no value for acetone extract, but for chloramphenicol antibiotics, $190 \mu \mathrm{g} / \mathrm{mL}$ of acetone extract concentration was required to inhibit 50\% growth of microorganisms. Furthermore, $430 \mu \mathrm{g} / \mathrm{mL}$ and $480 \mu \mathrm{g} / \mathrm{mL}$ of acetone extracts were required to inhibit C. albicans and C. parapsilosis yeasts, respectively. The concentration that was needed to inhibit $50 \%$ growth of microorganisms are $12 \mu \mathrm{g} / \mathrm{mL}$ (C. albicans) and $60 \mu \mathrm{g} / \mathrm{mL}$ (C. parapsilosis) for nystatin positive control.

Besides that, for ethanol and methanol extracts as well as five pure compounds, the no value shown in Table 1 did not mean the extracts and pure compounds were inactive, but the concentration of the samples were incapable of inhibiting 50\% growth of microorganisms, and perhaps by increasing the concentration of the samples, it will further increase the percentage of inhibits, which can reach $\mathrm{IC}_{50}$ values. Here it can be concluded 
that acetone extract was active against $\mathrm{IC}_{50}$ compared to other extracts. This was because the extract samples using acetone solvent did not caused the breakdown of chemical compounds as occurred in the extract using ethanol or methanol solvents (Joulain \& Tabacchi 2009b). The chemical compounds extracted from acetone solvent were more active and likely to inhibit the growth of bacteria and also yeast. Therefore, it can be concluded that the major compounds found in the acetone extract of lichen, Parmotrema praesorediosum were atranorin, chloroatranorin, and praesorediosic acids that had high minimum inhibitory concentration (MIC) when using broth dilution methods (Rajan et al. 2016).

TABLE $1 . \mathrm{IC}_{50}$ for each sample against bacteria and yeast

\begin{tabular}{|c|c|c|c|c|c|c|}
\hline \multirow[t]{2}{*}{$\begin{array}{l}\text { Extract, pure } \\
\text { compounds, antibiotic } \\
\text { and antiyeast }\end{array}$} & \multicolumn{6}{|c|}{ Inhibition concentration $50\left(\mathrm{IC}_{50}\right)(\mu \mathrm{g} / \mathrm{mL})$} \\
\hline & S. $a$ & $M R S A$ & E. $c$ & E. $a$ & C. $a$ & C. $p$ \\
\hline Acetone extract & 201 & - & - & - & 430 & 480 \\
\hline Ethanol Extract & - & - & - & - & - & - \\
\hline Methanol extract & - & - & - & - & - & - \\
\hline Methyl divaricatinate & - & - & - & - & - & - \\
\hline $\begin{array}{l}\text { Methyl } \\
\text { haematomamate }\end{array}$ & - & - & - & - & - & - \\
\hline $\begin{array}{l}\text { Methyl } \\
\text { clorohaematomate }\end{array}$ & - & - & - & - & - & - \\
\hline $\begin{array}{l}\text { Methyl } \\
\beta \text {-orsellinate }\end{array}$ & - & - & - & - & - & - \\
\hline $\begin{array}{l}\text { Vinapraesorediosic } \\
\text { acid }\end{array}$ & - & - & - & - & - & - \\
\hline Chloramphenicol & 110 & - & - & 190 & - & - \\
\hline Nystatin & - & - & - & - & 12 & 60 \\
\hline
\end{tabular}

Additionally, previous studies reported that atranorin in the acetone extract was able to inhibit the growth of positive Gram and negative Gram bacteria (Thadhani et al. 2012) while chloroatranorin was able to inhibit bacterial and fungal growths (Türk et al. 2006). Therefore, acetone extract can reach $\mathrm{IC}_{50}$ compared to methanol extract or ethanol extract. Most previous studies had used disk diffusion method to compare each of these extracts from lichen, Parmotrema praesorediosum. Balaji and Hariharan (2007) used disk diffusion method and found that the acetone extract of lichen, Parmotrema praesorediosum was active against $S$. aureus bacteria and Candida albicans yeast, while the methanol extract was inactive against bacteria and yeast. In addition, studies conducted on the same sample, Parmotrema praesorediosum using disk diffusion methods also found that methanol extract was active against $S$. aureus, $E$. coli, and E. aerogenes bacteria (Vivek et al. 2014b). In comparison to literature the results obtained were significantly different. These differences could be attributed to method variations, modification, and adaptation of species to survive in different location (Natrah et al. 2015) and weather in evaluating the biological potential of extracts and compounds. This difference was due to the modification and adaptation of species to survive in different places and weather (Rajan et al. 2015).

Furthermore, the disk diffusion method was different from the broth dilution method used in this study. Disk diffusion method is a qualitative analysis that will produce inaccuracy of reading, while broth dilution method is a quantitative analysis that will produce an accurate reading (Rajan et al. 2015). In addition, the disk 
diffusion method is not always reliable to determine the antimicrobial activity for natural antimicrobial agents, such as lichen extract because the polarity of natural compounds can affect the diffusion of compounds to media culture (Klančnik et al. 2010). This is because compounds with less polarity will not diffuse well compared to the more polar compounds (Eloff 2019).

Compared to the samples, antiyeast nystatin and antibiotic chloramphenicol showed the highest MIC and this indicates that antibiotics and antiyeast were very active and can inhibit bacterial and yeast growths. Based on the above results, each extract and pure compound has different sensitivity levels to yeast and bacteria due to the difference in transparency between cell walls (Nordin et al. 2014; Ristić et al. 2016). Gram positive of bacterial cell wall have a thick peptidoglycan with teichoic acid that can absorb antibiotics and clean up samples easily, including toxic. Gram negative bacteria have lipopolysaccharide and lipopolyprotein which are not transparent to antibiotics (Aziman et al. 2012; Epand et al. 2016) while the yeast cell walls have polysaccharides, such as chitin, glucan (Marijana et al. 2010), and membrane cells, ergosterol where the anti-yeast will stick to ergosterol and cause disturbance to the cell membrane fixation, which can cause yeast death if the dosage is used at a high level (Coutinho et al. 2004).

Ethanol and acetone extracts from the lichen, Parmotrema praesorediosum were analyzed by LCMS using Electron Soft Ionization technique (ESI). MZmine 2.10 is a software used for mass spectrometry data processing to make a comparison whether the solvents used will cause the breakdown of chemical components or not. In LC-MS, a high peak showed compounds with good ionization power. Based on the chromatogram in Figure 1, the red peak shows an acetone extract, the blue peak shows ethanol extract, while the methanol blank shows green peak. Based on the Dictionary Natural Product (DNP), atranorin compounds had ionizing peak at a retention time of 23.8. However, based on Figure 1, it is found that the peak of the retention time of 23.8 is not the main peak (low). In MZmine 2.10 software, good ionization compounds mean that they had higher peak although they are minor compounds. In this case, although atranorin is a main compound in lichen Parmotrema praesorediosum but atranorin is not a good ionization compound so that is why the peak of atranorin are low.

Figure 2 shows the chromatograms after magnification at a retention time from 22.5 to 24.5. Three peaks appear on the chromatogram where the red peak is an acetone extract, the blue peak is an ethanol extract and the green peak is methanol solvent. Clearly visible at the retention time of 23.8 , the blue peak is below the green peak, while the red peak is above the green peak. This clearly shows that at that retention, no compounds ionized in the ethanol extract, instead only ionized in the acetone extract. It can be concluded that the peaks on the ethanol extract was impurities, while in the acetone extract there was an atranorin compound.

Figure 3 shows the spectrum for the peak of atranorin compounds after magnification in the acetone extract only. The spectra shows the peak of atranorin compounds at $\mathrm{m} / \mathrm{z} 375.108\left[\mathrm{M}^{+} \mathrm{H}\right]^{+}$and $748.589[2 \mathrm{M}]^{+}$. Both $\mathrm{m} / \mathrm{z}$ values (atranorin compound) from of the ion molecules as shown in the chromatogram in Figure 2 prove that in the acetone extract, there was a compound of atranorin although atranorin was not a good ionization compound because its peak was shielded from good ionized compounds. $[2 \mathrm{M}]^{+}$is a mass number that arise from the presence of chlorine or bromine (isotope) in an organic compounds. The presence of significant amounts of heavier isotopes leads to small peaks that have masses that are higher than the parent ion peak.

Furthermore, Figure 4 shows the spectrum of ethanol extract only. The spectrum shows no value at peak $\mathrm{m} / \mathrm{z} 375.108$ and the nearest $\mathrm{m} / \mathrm{z}$ value was at $\mathrm{m} / \mathrm{z}$ 375.251. However, the value of $\mathrm{m} / \mathrm{z} 375.251$ was not a value of the atranorin compound, but it was the value of the impurities found in the solvent. This spectrum also proves the chromatogram in Figure 2 that there was no atranorin compound at that $\mathrm{m} / \mathrm{z}$ values, but there were only impurities in the analysis sample. We can say that the peak belongs to impurities because at $\mathrm{m} / \mathrm{z} 375.251$ in DNP, there is no compounds at that molecular weight in parmotrema species that matched with it.

Figure 5 shows a scatter plot where the aim of scattering plot was to compare the intensity and distribution of the difference in $\mathrm{m} / \mathrm{z}$ ratio in two different extracts. From Figure 5, in acetone extract, there is a yellow spot which belongs to atranorin based on retention time at $23.8, \mathrm{~m} / \mathrm{z}$ value of $375.108\left[\mathrm{M}^{+} \mathrm{H}\right]^{+}$and same molecular formula, $\mathrm{C} 19 \mathrm{H} 18 \mathrm{O} 8$. These yellow spots appeared only in the acetone extract and did not appear in the ethanol extract. This was because if this atranorin compound was present in both extracts, then the yellow spot representing the atranorin compound will be in the distribution at the center of the graph. Therefore, this scattered plot also proves that the atranorin compound was only found in the acetone extract and was not found in the ethanol extract.

Chemically, these bonding cleavages happen because the ester bond of the main compound has been broken down by alcohol solvents and the alcoholysis or hydrolysis process has occurred. This ester bond makes the main bond of the depside group (atranorin) break. This ester bond exists in the depside group and atranorin is a 
compound that comes from the depside group (Stojanović et al. 2011; Vos et al. 2018).

The breakdown of ester bond will produce other compounds from the aromatic monocyclic group, which are methyl $\beta$-orsellinate and haematommic acid that occur as a result of hydrolysis process (Joulain \& Tabacchi $2009 \mathrm{~b}$ ). Haematommic acid is formed in the form of ethyl esters and it is easy to break the bond (Joulain \& Tabacchi 2009a). Therefore, when the alcoholysis process occurs due to the use of alcohol solvent (ethanol), it will produce ethyl haematommate compound. Ethyl haematommate compound may be artifacts from the extraction method using the ethanol solvent. Besides, decarboxylation of haematommic acid yields atranol. The separation process for atranorin compound can be seen in Figure 6 as proposed pathway (Stojanović et al 2011; Vos et al. 2018). The type of alcohol solvents used will influence the result of the chemical compound, for example, extraction using ethanol solvent will produce ethyl haematommate or ethyl chlorohaematommate, while isopropyl haematommate compound will be produced from the extraction process using isopropanol solvent (Joulain \& Tabacchi 2009b)

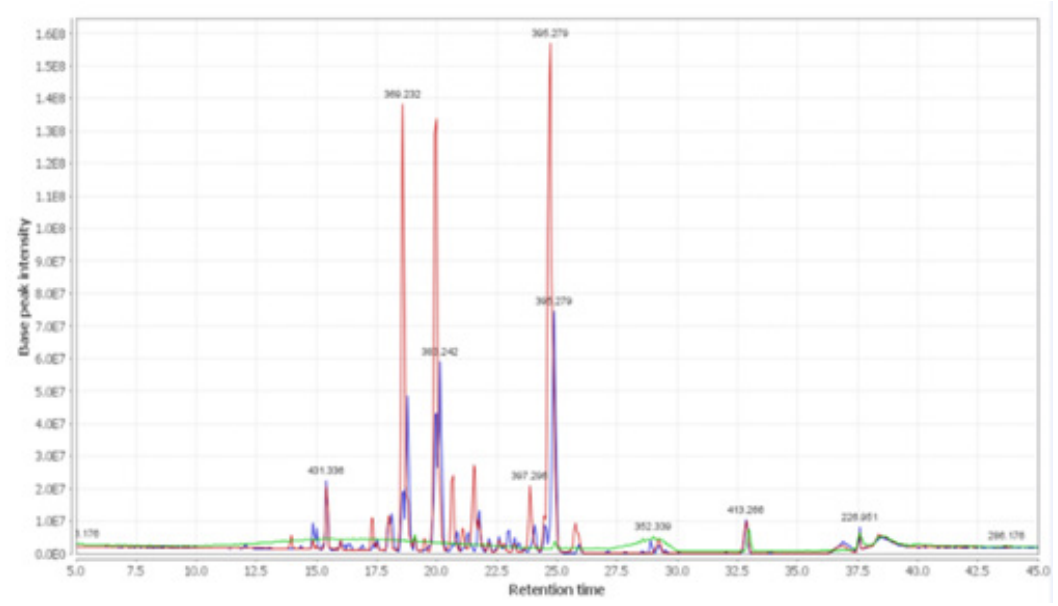

FIGURE 1. LC-MS chromatogram for extract acetone (red), extract (blue) and methanol blank (green)

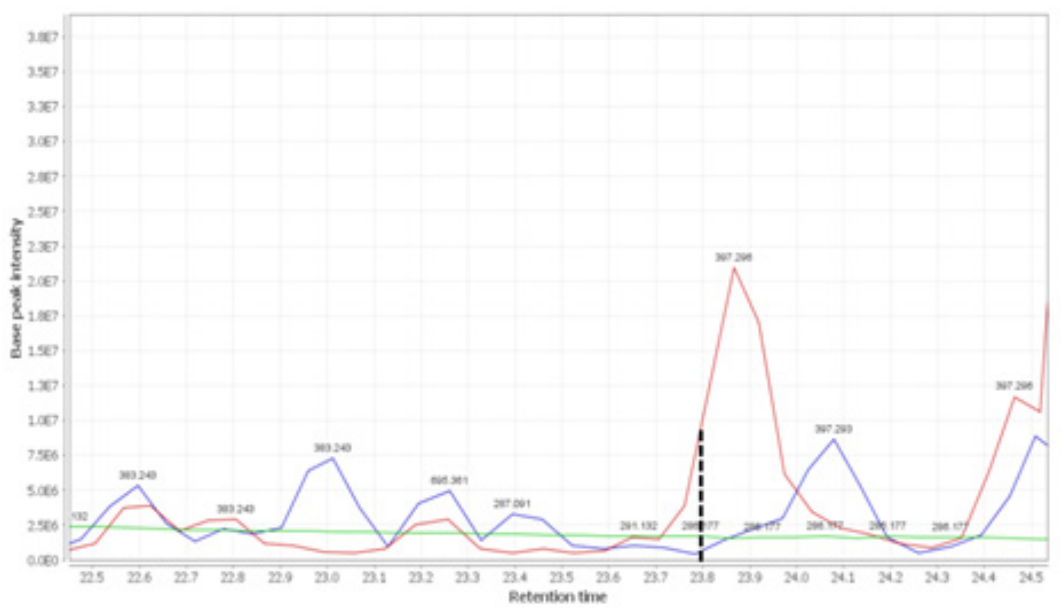

FIGURE 2. LC-MS chromatogram for acetone extract (red), ethanol extract (blue) and methanol blank (green) after magnification 


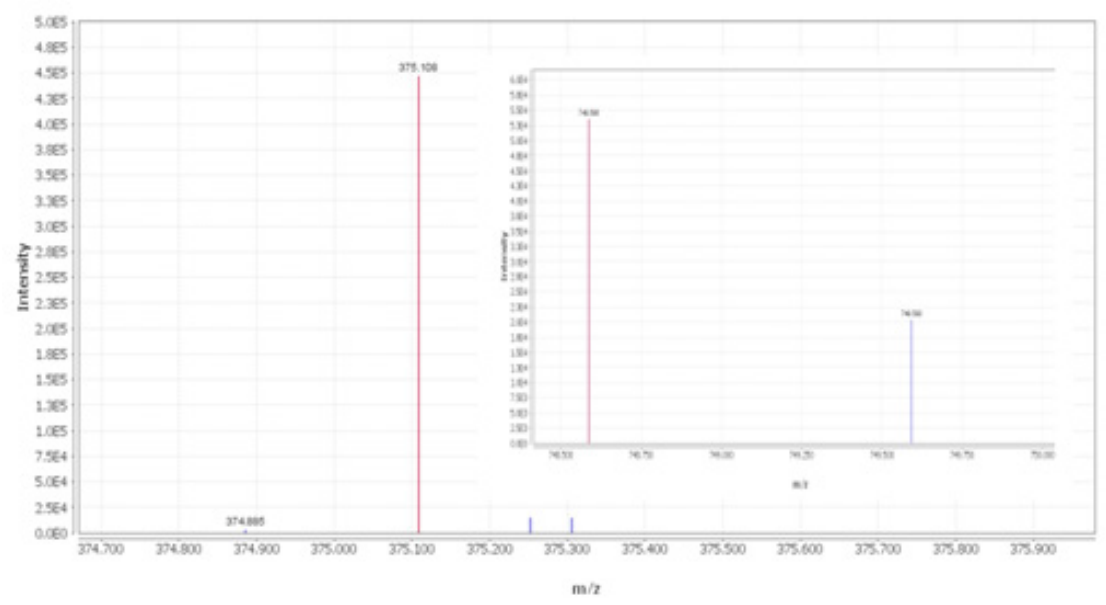

FIGURE 3. Value of $\mathrm{m} / \mathrm{z}$ ion molecule of $[\mathrm{M}+\mathrm{H}]^{+}$and $[2 \mathrm{M}]^{+}$for atranorin compound in acetone extract

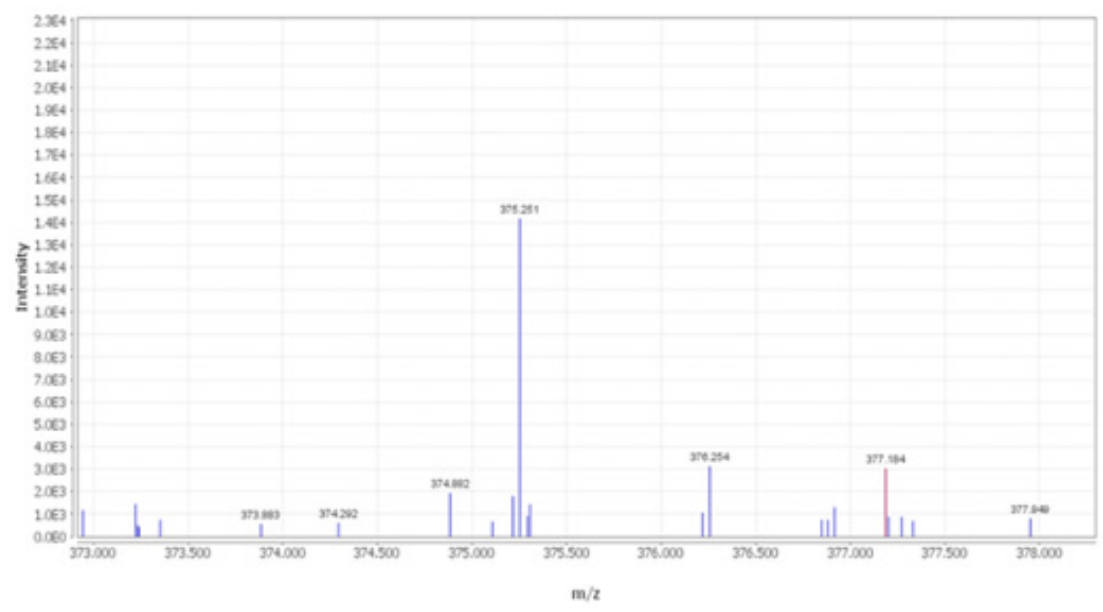

FIGURE 4. Value of $\mathrm{m} / \mathrm{z}$ ion molecule $[\mathrm{M}+\mathrm{H}]^{+}$for compounds in ethanol extract

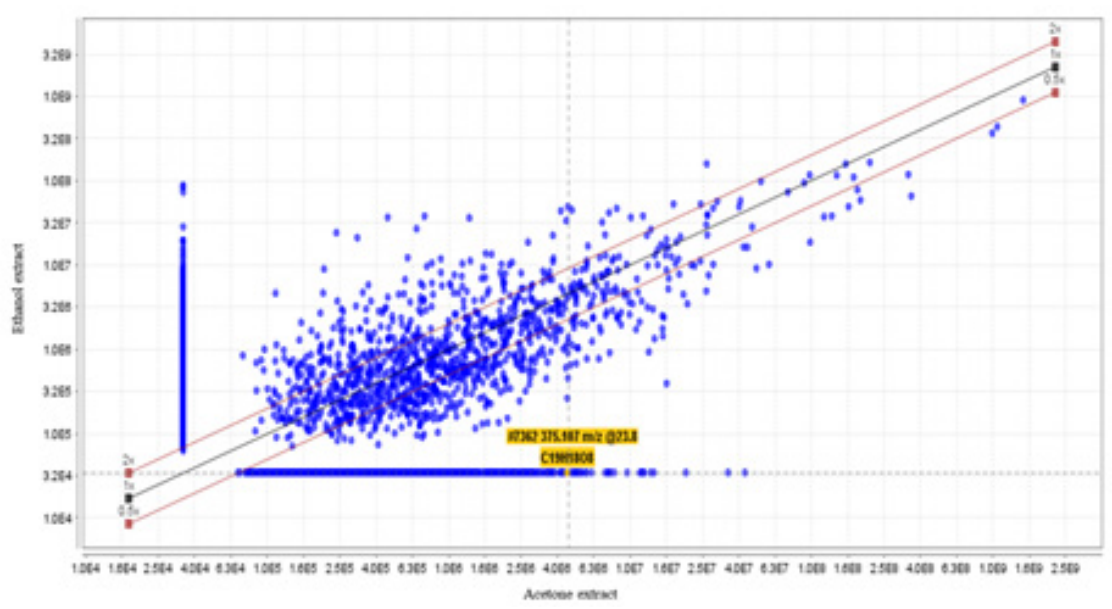

FIGURE 5. Scatter plot for ethanol extract and acetone extract 
<smiles>[R]c1c(C)c(C(=O)Oc2c(C)c(C)c(C(=O)OC)c(O)c2C)c(O)c(C=O)c1O</smiles>

Atranorin $\mathrm{R}=\mathrm{H}$

Chloroatranorin $\mathrm{R}=\mathrm{Cl}$

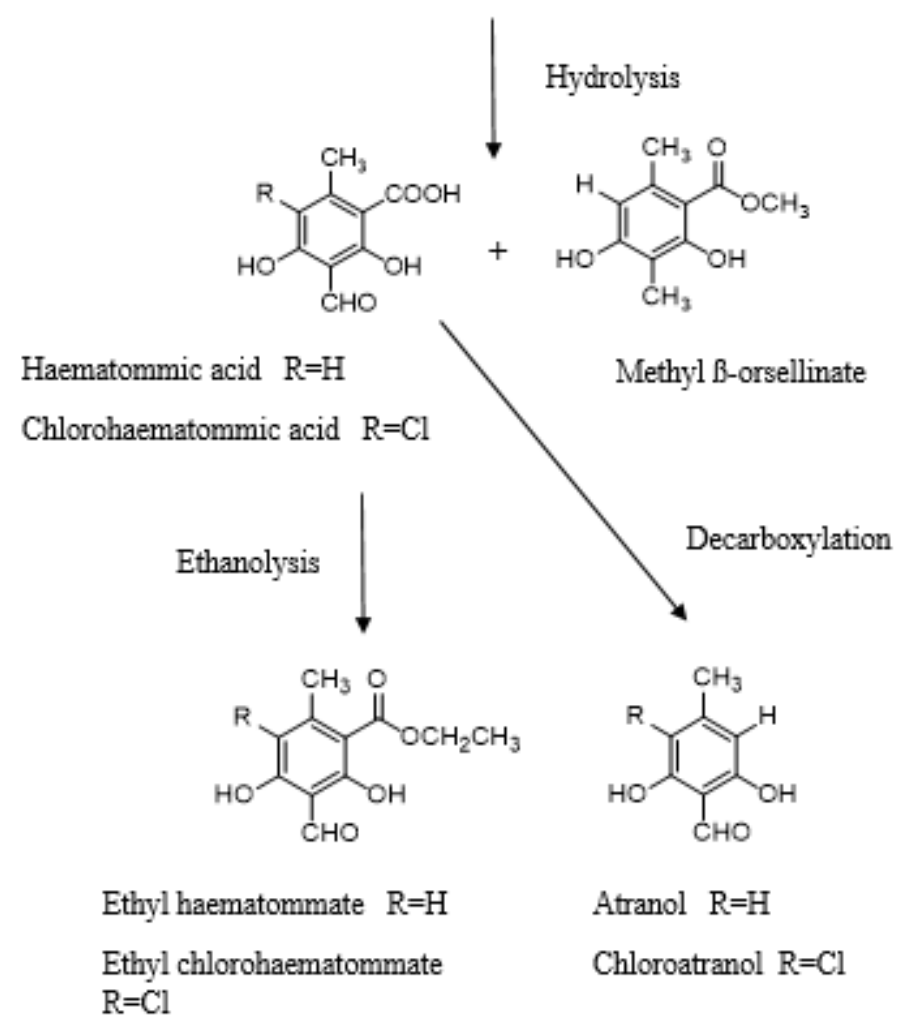

FIGURE 6. Proposed pathway process occurred in atranorin compound

Furthermore, from this research, the lichen, Parmotrema praesorediosum had been extracted with methanol solvent and three compounds had been isolated, which were methyl $\beta$-orsellinate, methyl haematommate, and methyl chlorohaematommate. These three compounds came from the breakdown of the main compound, atranorin. It has been proven that extraction using methanol solvents causes the breakdown of compounds.

In general, the hydrolysis process in the lichen occurs in the presence of water whether hot water, warm water or steam where the effect is the breakdown of the compound bond during the extraction process. Based on a previously reported study, the hydrolysis and decarboxylation process for this atranorin compound or chloroatranorin not only occur when the process of extraction or purification is carried out, but it may also occur on the lichen 'life' itself. This occurs when the lichens are attached to a tree with a humidity of $15-20 \%$ without any artificial treatment (Joulain \& Tabacchi 2009b).

The comparison of LC-MS data for ethanol and acetone extracts are necessary to determine which solvent is suitable to be used during the extraction process in order to obtain the major chemical components in lichen, Parmotrema praesorediosum which is atranorin compound. Previous studies had reported that these 
atranorin compounds have many uses in the pharmaceutical industry. For example, these compounds can act as antimicrobials, antioxidants, anticancer, wound healing (Studzinska-Sroka et al. 2017) as compared to the minor compounds obtained in this research study, which were methyl $\beta$-orsellinate, methyl haematommate and methyl chlorohaematommate compounds. In addition, the way of the storage of the sample, separation and purification methods also need to be done carefully so that the main compound bond will not break.

\section{CONCLUSION}

This is the first report on the antimicrobial activity for determining $\mathrm{IC}_{50}$ values using broth dilution method for five pure compounds extracted from methanol solvents in lichen, Parmotrema praesorediosum from Bangi, Selangor, Malaysia. Ethanol and methanol extracts and their pure compounds did not reach $\mathrm{IC}_{50}$ because the breakdown of main components occurred and vice versa for acetone. The LC-MS data proved that chemical breakdown only occurred in the ethanol extract.

\section{ACKNOWLEDGEMENTS}

The authors gratefully acknowledge the financial support provided by GUP-2017-103 for providing all the necessary support in conducting this research article.

\section{REFERENCES}

Altemimi, A., Lakhssassi, N., Baharlouei, A., Watson, D.G. \& Lightfoot, D.A. 2017. Phytochemicals: Extraction, isolation, and identification of bioactive compounds from plant extracts. Plants 6(42): 1-23.

Aziman, N., Abdullah, N., Mohd Noor, Z., Zulkifli, K.S. \& Wan Kamarudin, W.S.S. 2012. Phytochemical constituents and in vitro bioactivity of ethanolic aromatic herb extracts. Sains Malaysiana 41(11): 1437-1444.

Balaji, P. \& Hariharan, G.N. 2007. In vitro antimicrobial activity of Parmotrema praesorediosum. Research Journal of Botany 2(1): 54-59.

Chauhan, R. \& Abraham, J. 2013. In vitro antimicrobial potential of the lichen Parmotrema sp. extracts against various pathogens. Iranian Journal of Basic Medical Sciences 16(7): 881-885.

Coutinho, A., Silva, L., Fedorov, A. \& Prieto, M. 2004. Cholesterol and ergosterol influence nystatin surface aggregation: Relation to pore formation. Biophysical Journal 87(5): 3264-3276.

Dai, J. \& Mumper, R.J. 2010. Plant phenolics: Extraction, analysis and their antioxidant and anticancer properties. Molecules 15(10): 7313-7352.

Din, L.B., Zakaria, Z., Samsudin, M.W. \& Elix, J.A. 2010. Chemical profile of compounds from lichens of Bukit Larut, Peninsular Malaysia. Sains Malaysiana 39(6): 901908.
Eloff, J.N. 2019. Avoiding pitfalls in determining antimicrobial activity of plant extracts and publishing the results. BMC Complementary and Alternative Medicine 19(106): 1-8.

Epand, R.M., Walker, C., Epand, R.F. \& Magarvey, N.A. 2016. Molecular mechanisms of membrane targeting antibiotics. BBA - Biomembranes 1858(5): 980-987.

Goga, M., Elečko, J., Marcinčinová, M., Ručová, D., Bačkorová, M. \& Bačkor, M. 2018. Lichen metabolites: An overview of some secondary metabolites and their biological potential. In Co-Evolution of Secondary Metabolites, edited by Mérillon, J.M. \& Ramawat, K.G. Switzerland: Springer. pp. 175-209.

Huynh, B.L.C. 2014. Study on chemical constituents and biological activities of four lichens growing in the South of Vietnam. Ph.D Thesis, Vietnam National University (Unpublished).

Huynh, B.L.C., Duong, H.L., Takenaka, Y., Tanahashi, T. \& Nguyen, K.P.P. 2016. New phenolic compounds from the lichen Parmotrema praesorediosum (Nyl.) hale, (Parmeliaceae). Magnetic Resonance Chemistry 54(1): 81-87.

Jahromi, S.G. 2019. Extraction techniques of phenolic compounds from plants. In Plant Physiological Aspects of Phenolic Compounds, edited by Soto-Hernández, M., García-Mateos, R. \& Palma-Tenango, M. London: IntechOpen. pp. 1-18.

Jim, O.N. 2014. Antimicrobial Resistance: Tackling a Crisis for the Health and Wealth of Nations. United Kingdom: Wellcome Trust.

Joshi, D.R. \& Adhikari, N. 2019. An overview on common organic solvents and their toxicity. Journal of Pharmaceutical Research International 28(3): 1-18.

Joulain, D. \& Tabacchi. R. 2009a. Lichen extracts as raw materials in perfumery. Part 1: Oakmoss. Flavour and Fragrance Journal 24(2): 49-61.

Joulain, D. \& Tabacchi. R. 2009b. Lichen extracts as raw materials in perfumery. Part 2: Treemoss. Flavour and Fragrance Journal 24(3): 105-116.

Klančnik, A., Piskernik, S., Jeršek, B. \& Možina, S.S. 2010. Evaluation of diffusion and dilution methods to determine the antibacterial activity of plant extracts. Journal of Microbiological Methods 81(2): 121-126.

Kosanić, M. \& Ranković, B. 2015. Lichen secondary metabolites as potential antibiotic agents. In Lichen Secondary Metabolites, edited by Ranković, B. Switzerland: Springer International Publishing. pp. 81-104.

Mahdavi, B., Yaacob, W.A. \& Din, L.B. 2017. Antioxidant and antimicrobial activity of the extracts from different parts of Etlingera sayapensis (Zingiberaceae). Sains Malaysiana 46(9): 1565-1571.

Mahira, S., Jain, A., Khan, W. \& Domb, A.J. 2019. Antimicrobial materials - An overview. In Antimicrobial Materials for Biomedical Applications, edited by Domb, A.J., Kunduru, K.R. \& Farah, S. United Kingdom: Royal Society of Chemistry. pp. 1-37.

Marijana, K., Branislav, R. \& Slobodan, S. 2010. Antimicrobial activity of the lichen Lecanora frustulosa and Parmeliopsis 
hyperopta and their divaricatic acid and zeorin constituents. African Journal of Microbiology 4(9): 885890.

Minatel, I.O., Borges, C.V., Ferreira, M.I., Gomez, H.A.G., Chen, C.Y.O. \& Lima, G.P.P. 2017. Phenolic compounds: Functional properties, impact of processing and bioavailability. In Phenolic Compounds - Biological Activity, edited by Soto-Hernandez, M., Palma-Tenango, M. \& GarciaMateos, R. London: IntechOpen. pp. 1-24.

Natrah, F.M.I., Harah, Z.M., Sidik, B.J., Izzatul, N.M.S. \& Syahidah, A. 2015. Antibacterial activities of selected seaweed and seagrass from Port Dickson coastal water against different aquaculture pathogens. Sains Malaysiana 44(9): 1269-1273.

Niaounakis, M. 2013. Definitions and assessment of (bio) degradation. Biopolymers Reuse, Recycling, and Disposal. United Kingdom: William Andrews Applied Science Publishers. pp. 77-94.

Nordin, N., Mohan, S., Hashim, N.M., Zajmi, A., Yazid, N.S.M., Rahman, M.A., Omer, F.A.A., Omar, H., Alias, F.A.F. \& Ali, H.M. 2014. Antioxidant, anticancer and antimicrobial activities of methanolic extracts from Enicosanthellum pulchrum (king) heusden. Sains Malaysiana 43(10): 15151521.

Rajan, V.P., Gunasekaran, S., Ramanathan, S., Murugaiyah, V., Samsudin, M.W. \& Din, L.B. 2016. Biological activities of four Parmotrema species of Malaysian origin and their chemical constituents. Journal of Applied Pharmaceutical Science 6(8): 36-43.

Rajan, V.P., Gunasekaran, S., Ramanathan, S., Murugaiyah, V., Samsudin, W. \& Din, L.B. 2015. Antibacterial activity of extracts of Parmotrema praesorediosum, Parmotrema rampoddense, Parmotrema tinctorum, and Parmotrema reticulatum. AIP Conference Proceedings 1678(1): 1-4.

Ranković, B. \& Kosanić, M. 2015. Lichens as a potential source of bioactive secondary metabolites. In Lichen Secondary Metabolites, edited by Ranković, B. Switzerland: Springer International Publishing. pp. 1-29.

Ristić, S., Ranković, B., Kosanić, M., Stanojković, T., Stamenković, S., Vasiljević, P., Manojlović, I. \& Manojlović, N. 2016. Phytochemical study and antioxidant, antimicrobial and anticancer activities of Melanelia subaurifera and Melanelia fuliginosa lichens. Journal of Food Science and Technology 53(6): 2804-2816.

Stojanović, I.Ž., Radulović, N.S., Mitrović, T.L., Stamenković, S.M. \& Stojanović, G.S. 2011. Volatile constituents of selected Parmeliaceae lichens. Journal of the Serbian Chemical Society 76(7): 987-994.

Studzinska-Sroka, E., Galanty, A. \& Bylka, W. 2017. Atranorin - an interesting lichen secondary metabolite. Mini-Reviews in Medicinal Chemistry 17(17): 1633-1645.
Thadhani, V.M., Choudhary, M.I., Khan, S. \& Karunaratne, V. 2012. Antimicrobial and toxicological activities of some depsides and depsidones. Journal of the National Science Foundation of Sri Lanka 40(1): 43-48.

Thell, A., Crespo, A., Divakar, P.K., Kärnefelt, I., Leavitt, S.D., Lumbsch, H.T. \& Seaward, M.R.D. 2012. A review of the lichen family Parmeliaceae - history, phylogeny and current taxonomy. Nordic Journal of Botany 30(6): 641-664.

Türk, H., Yilmaz, M., Tay, T., Türk, A.Ö. \& Kivanç, M. 2006. Antimicrobial activity of extracts of chemical races of the lichen Pseudevernia furfuracea and their physodic acid, chloroatranorin, atranorin, and olivetoric acid constituents. Zeitschrift für Naturforschung C 61(7-8): 499-507.

Vivek, M.N., Manasa, M., Kambar, Y., Prashith Kekuda, T.R. \& Raghavendra, H.L. 2014a. Antifungal efficacy of three bioactive Parmotrema species from Western Ghats of Karnataka, India. International Journal of Agriculture and Crop Sciences 7(12): 968-973.

Vivek, M.N., Kambar, Y., Manasa, M., Prashith Kekuda, T.R. \& Vinayaka, K.S. 2014b. Radical scavenging and antibacterial activity of three Parmotrema species from Western Ghats of Karnataka, India. Journal of Applied Pharmaceutical Sciences 4(3): 86-91.

Zhang, Q.W., Lin, L.G. \& Ye, W.C. 2018. Techniques for extraction and isolation of natural products: A comprehensive review. Chinese Medicine 13(20): 1-26.

Anis Asmi Azman, Nurul Nadiah, Andi Rifki Rosandy, Rozida Mohd Khalid \& Muntaz Abu Bakar*

School of Chemical Science and Food Technology

Faculty of Science and Technology

Universiti Kebangsaan Malaysia

43600 UKM Bangi, Selangor Darul Ehsan

Malaysia

Afnani Alwi

School of Biological Science

Faculty of Science and Technology

Universiti Kebangsaan Malaysia

43600 UKM Bangi, Selangor Darul Ehsan

Malaysia

Nurkhalida Kamal

Faculty of Pharmaceutical

Cyberjaya University College of Medical Science

63000 Cyberjaya, Selangor Darul Ehsan

Malaysia

*Corresponding author; email: muntaz@ukm.edu.my

Received: 20 May 2020

Accepted: 12 July 2020 